\title{
Pulleniatina Minimum Event during the last deglacia- tion in the southern South China Sea
}

\author{
AN Yang ${ }^{\dagger} \&$ JIAN ZhiMin \\ State Key Laboratory of Marine Geology, Tongji University, Shanghai 200092, China
}

The planktonic foraminiferal faunal census of core MD $05-2894\left(7^{\circ} 2.25^{\prime} \mathrm{N}, 111^{\circ} 33.11^{\prime} \mathrm{E}\right.$, water depth 1982 $\mathrm{m}$ ), retrieved from the southern South China Sea (SCS) during the "Marco Polo" cruise in 2005, was performed to investigate the abundance changes of a subsurface dweller, Pulleniatina obliquiloculata. The results display that the abundance of $P$. obliquiloculata nearly declines to zero during $16.0-14.9 \mathrm{ka}$, corresponding to the Heinrich 1 (H1) cold interval. The unexpected decrease of $P$. obliquiloculata occurs in the adjacent cores, roughly between 17 and 14.8 ka based on the previous studies. Accordingly, the Pulleniatina Minimum Event in the last deglaciation can serve as a good stratigraphical indicator, at least in the southern SCS. To further explore the changes of sea surface temperature (SST) and subsurface seawater temperature (SSST), we made parallel Mg/Ca measurements on surface dweller Globigerinoides ruber and subsurface dweller $P$. obliquiloculata tests. Since the last deglaciation, the SSTs show a continuous increasing trend towards the late Holocene, while the warming of the subsurface water is punctuated by a $2^{\circ} \mathrm{C}$-cooling interval across the deglacial Pulleniatina Minimum Event. Both increased $\delta^{18} O$ differences between $G$. ruber and $P$. obliquiloculata, and increased temperature differences between surface and subsurface water suggest a shoaling of the mixed layer during the deglacial Pulleniatina Minimum Event. Therefore, we consider that the significant changes in the upper ocean structure are responsible for the Pulleniatina Minimum Event during the last deglaciation in the southern SCS.

Pulleniatina Minimum Event, subsurface seawater temperature, upper ocean structure, the last deglaciation, the southern South China Sea

Pulleniatina obliquiloculata, a tropical subsurface dwelling planktonic foraminifer, calcifies most of its test below the mixed layer. In the global ocean, its highest abundance in surface sediments occurs in a relatively narrow belt between about $10^{\circ} \mathrm{N}$ and $10^{\circ} \mathrm{S}$, which coincides generally with the equatorial current systems in the Atlantic, Indian and Pacific Oceans ${ }^{[1]}$. High concentrations (more than 20\%) of the species are found in the western equatorial Pacific and the northern South China Sea (SCS) ${ }^{[1,2]}$. Previous studies in northwestern Pacific ${ }^{[3]}$ and the northern $\mathrm{SCS}^{[2]}$ demonstrate that $P$. obliquiloculata is closely related to warm and saline currents like the Kuroshio Current. Sediment traps from the northern SCS show that $P$. obliquiloculata occurs during the winter monsoon ${ }^{[4]}$. So it is believed that the abundance of $P$. obliquiloculata is closely related to subsurface seawater temperatures (SSSTs), especially SSSTs in winter, and the depth of thermocline (DOT). Studies on this species have become an important issue in paleoceanography of the western Pacific ${ }^{[5-8]}$.

Paleoceanographers have documented an extremely low abundance of $P$. obliquiloculata between 4.5 and 3.0 cal. $\mathrm{ka}$ in deep sea sediment cores in Okinawa Trough ${ }^{[5,6,9-11]}$ and the northern SCS $^{[12]}$, which is defined as "Pulleniatina Minimum Event" (PME). It correlates well with the Chinese lake ${ }^{[13]}$ and stalagmite ${ }^{[14]}$ records,

Received November 5, 2008; accepted March 5, 2009, published online May 15, 2009 doi: 10.1007/s11434-009-0290-4

Corresponding author (email: anyang820916@gmail.com)

Supported by National Basic Research Program of China (Grant No.2007CB815900), National Natural Science Foundation of China (Grant No. 40621063) and China Ocean Mineral Resources Research and Development Association (Grant No. DY 115-01-2-3) 
which show the weakening of East Asian summer monsoon during this period. Previous studies ascribed the Holocene PME to the track and intensity changes of Kuroshio or the decline of winter sea surface temperatures (SSTs) ${ }^{[5,6,9,11]}$. During the last deglacial warming period, there is another low abundance of $P$. obliquiloculata in the southern SCS similar to the late Holocene PME. In this study, we'll try to understand when, where and why this event happens so as to get a better understanding of the paleoceanographic changes in the southern SCS during the last deglaciation.

\section{Materials and methods}

MD 05-2894 (lat. $7^{\circ} 2.25^{\prime} \mathrm{N}$, long. $111^{\circ} 33.11^{\prime} \mathrm{E}$, Figure 1 , 1982 m water-depth; MD 94 henceforth), retrieved from the southern SCS during the "Marco Polo" cruise in 2005 , is a $10.85 \mathrm{~m}$ long CASQ core free of turbidites. 230 samples were sampled in the upper $467 \mathrm{~cm}$ with an interval of $2 \mathrm{~cm}$ for oxygen, carbon isotopic and $\mathrm{Mg} / \mathrm{Ca}$ measurements on surface dweller Globigerinoides ruber and subsurface dweller P. obliquiloculata. All laboratory methods can be referred to ref. [15] and all experiments were completed at State Key Lab of Marine Geology, Tongji University. The $>154 \mu \mathrm{m}$ fraction of each sample (with the sampling interval of $2-4 \mathrm{~cm}$ ) was split into an aliquot containing 200 to 300 specimens. Main species, such as G. ruber, Globigerinoides sacculifer, P. obliqui loculata and Neogloboquadrina dutertrei, were counted. To construct the precise age model, 7 samples (Table 1)

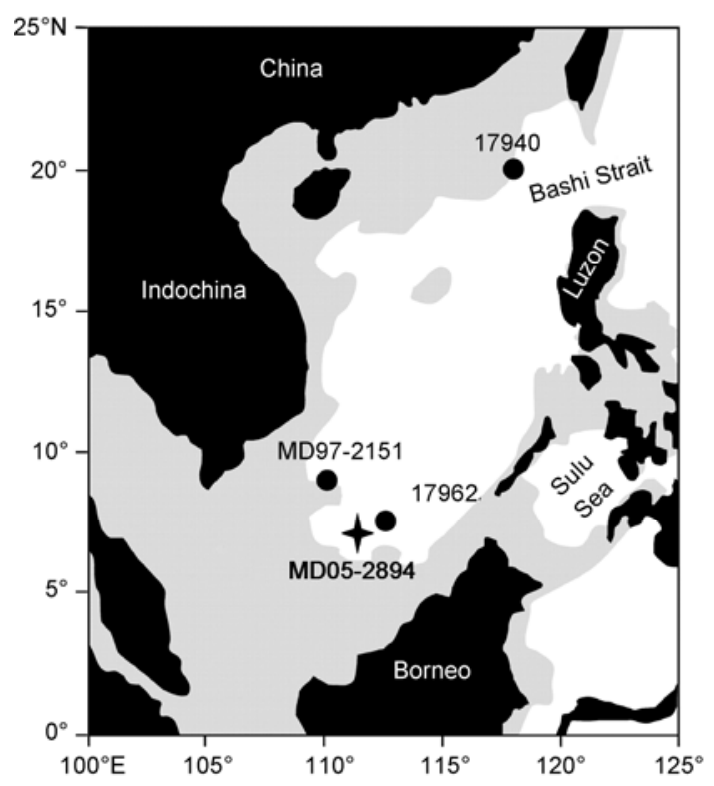

Figure 1 Locations of cores in the southern SCS related to this study. consisting of mixed tests of $G$. ruber and $G$. sacculifer (800-1200 specimens, $>154 \mu \mathrm{m}$ ) were subjected to AMS ${ }^{14} \mathrm{C}$ dating at Peking University. The results were converted to calendar years based on Fairbanks et al.'s ${ }^{[16]}$ method and CALIB 5.0 software, respectively. Few differences occurred between 12.41 ka BP and the present. From 11.9 to $14 \mathrm{ka}$, the dataset used by CALIB 5.0 includes predominantly laminated sediments from the $\mathrm{Ca}-$ riaco Basin, along with coral data from numerous investigators of varying sample quality, in contrast, Fairbanks et al.'s ${ }^{[16]}$ dataset uses the 1382-ring floating tree ring data. We use the latter method to construct our age model because it is more accurate and widely cited.

Table 1 AMS ${ }^{14} \mathrm{C}$ datings of MD 05-2894

\begin{tabular}{ccc}
\hline Depth $(\mathrm{cm})$ & AMS $^{14}$ C years $(\mathrm{a} \mathrm{BP}( \pm 1 \sigma))$ & Cal. years $(\mathrm{a} \mathrm{BP})$ \\
\hline 62.5 & $5010 \pm 35$ & $5337 \pm 56$ \\
104.5 & $6765 \pm 40$ & $7289 \pm 42$ \\
140.5 & $10825 \pm 45$ & $12324 \pm 105$ \\
188.5 & $13195 \pm 50$ & $14909 \pm 101$ \\
214.5 & $13285 \pm 45$ & $15012 \pm 103$ \\
284.5 & $13785 \pm 50$ & $15584 \pm 121$ \\
368.5 & $14890 \pm 65$ & $17117 \pm 177$ \\
\hline
\end{tabular}

\section{Results and discussion}

The precise age model is established based on the calendar years converted from the AMS ${ }^{14} \mathrm{C}$ dating results. The studied interval covers about 18.9 cal. ka (All ages discussed henceforth are calendar ages), with an average time resolution of 82 a. The sedimentation rate (SR) varies much among different time intervals. The upper $134.5 \mathrm{~cm}$ Holocene samples have a low average SR of $11.7 \mathrm{~cm} / \mathrm{ka}$; while the lower part has a relatively high S$\mathrm{R}$ of $46.2 \mathrm{~cm} / \mathrm{ka}$ in average, with its maximum of 252.4 $\mathrm{cm} / \mathrm{ka}$ (Figure 2(c)). The $8 \mathrm{a} /$ sample-resolution then is the highest temporal resolution till now for the late Quaternary paleoceanographic study in the southern SCS.

The oxygen isotope values of G. ruber show an obvious glacial/interglacial cycle, varying between -0.89 $4 \%$ and $-3.492 \%$ (Figure 2(a)). During the early stage of the deglaciation $(15-18.9 \mathrm{ka})$, the $\delta^{18} \mathrm{O}$ of $G$. ruber fluctuated around $-1.7 \%$, and then became more negative to $-3.0 \%$ in the Holocene. $\delta^{18} \mathrm{O}$ of $P$. obliquiloculata vary in a similar trend to that of G. ruber (Figure 2(b)), but shows heavier values of $-0.1 \%$ and $-1.3 \%$ in the early deglaciation and the Holocene, respectively. $\delta^{18} \mathrm{O}$ of $G$. ruber have an average difference of $1.3 \%$ 
between the early deglaciation and the Holocene, which is a little larger than that (1.2\%o) of P. obliquiloculata. Furthermore, both species have clear responds to the Younger Dryas event $(13.2-11.5 \mathrm{ka})$, with reduced oxygen isotopes by $\sim 1.0 \%$ and $\sim 0.8 \%$, respectively (Figure 2). Such changes clearly indicate the existence of millennial-scale climate fluctuations like the Younger Dryas event in the southern SCS.

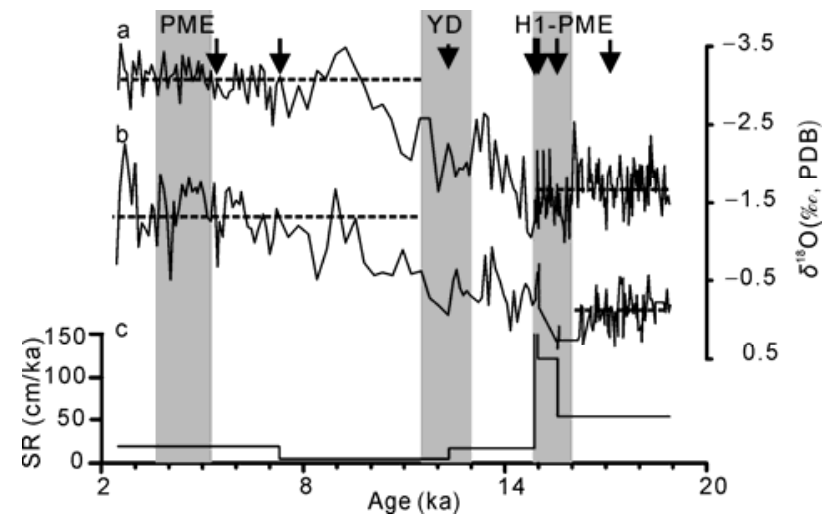

Figure 2 Oxygen isotopic records of planktonic foraminifera and the sedimentation rate in core MD 05-2894. a, G. ruber. b, P. obliquiloculata; c, sedimentation rate. PME is the Holocene Pulleniatina Minimum Event, and YD is Younger Dryas event. H1-PME is the deglacial Pulleniatina Minimum Event correlating to $\mathrm{H} 1$ event. Average values of various periods are represented by the dotted lines. Arrows show the AMS ${ }^{14} \mathrm{C}$ radiocarbon datings.

It is indicated by the faunal census data that the abundance of P. obliquiloculata varies from 0 to $21.6 \%$ from the last glacial maximum (LGM) to present, with an average of $5.4 \%$. The abundance of this species shows a decreasing trend since the last deglaciation. Its highest abundance is documented in the early deglaciation (16.2 $\mathrm{ka}$; Figure 3(b)), while its lowest concentrations are recorded during two time-intervals, $3.7-5.2 \mathrm{ka}$ and $14.9-$ 16.0 ka. P. obliquiloculata has a very low abundance of $1.9 \%$ in average, with its lowest value of $0.4 \%$ during $3.7-5.2 \mathrm{ka}$. This section correlates well with the Holocene PME which is extensively documented in marginal seas of the western Pacific ${ }^{[5,6,9-11]}$. But after the PME, the abundance is still lower than the early Holocene in the southern SCS, which is different from that in the northern SCS (Figure 3(a)) and Okinawa Trough ${ }^{[12]}$. What's more, P. obliquiloculata shows another dramatically low abundance between 14.9 and $16.0 \mathrm{ka}$. The average abundance of $1.1 \%$ is obviously lower than that of the upper and lower parts of this core (usually greater than $10 \%$ ). This event lasts for $1.1 \mathrm{ka}$ from 16.0 to 14.9 ka (Figure 3(b)) and correlates well with the Heinrich 1 event, so we define it as H1-PME. Comparing the result with that of the adjacent cores such as $17962^{[18]}$ and MD97-2151 $1^{[19]}$, we will see that the H1-PME extensi- vely occurs in the southern SCS, roughly between 17 and $14.8 \mathrm{ka}$. But no such event exists in the northern SCS $\left(17940^{[17]}\right.$, Figure 3(a)), so the H1-PME may be a unique event and can be a good stratigraphical indicator in the southern SCS.

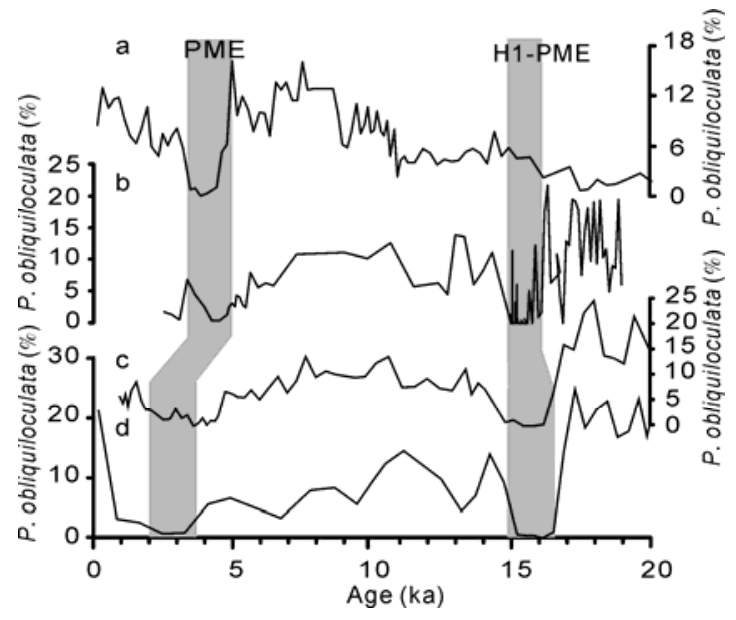

Figure 3 The abundance of $P$. obliquiloculata of various cores in the southern SCS and 17940 in the northern SCS. a, 17940 ${ }^{[17]} ; \mathrm{b}, \mathrm{MD}$ 05-2894, this study; c, $17962^{[18]}$; d, MD97-2151 ${ }^{[19]}$. PME is the Holocene Pulleniatina Minimum Event; $\mathrm{H} 1-\mathrm{PME}$ is the deglacial Pulleniatina Minimum Event correlating to $\mathrm{H} 1$ event.

Paleoceanographers have thoroughly investigated the Holocene PME. They first ascribed this event to winter SST declines ${ }^{[5,12]}$, further studies concluded that track and intensity changes of Kuroshio Current might also cause the event ${ }^{[5,6,9,11]}$, and also considered ENSO factor ${ }^{[20]}$. Lin et al. ${ }^{[10]}$ has performed multi-species isotopic analysis and G. ruber $\mathrm{Mg} / \mathrm{Ca} \mathrm{SST}$ reconstructions. Based on the data in the western Pacific marginal seas (mainly in Okinawa Trough and SCS), she insisted on that the Holocene PME be independent of any above-mentioned paleoceanographic changes. Till now we indeed can not attribute the Holocene PME in the southern SCS (Figure 3) to variations of Kuroshio Current; we can not expect decreases of $\mathrm{Mg} / \mathrm{Ca}$-derived SSTs in Okinawa Trough $^{[10,21]}$ or the southern $\mathrm{SCS}^{[22,23]}$, either. According to the numerical simulation study ${ }^{[20]}$, El Niño strengthened after the Holocene PME, which is contradictory to the ENSO hypothesis. Observed only in the southern SCS, H1-PME may have a reason completely different from that occurred in the Holocene, which means $\mathrm{Ku}$ roshio can not be the triggering factor. No obvious SST declines are documented in the southern SCS during H1- 
$\mathrm{PME}^{[20]}$, so SST changes are not the cause. Then we must divert our attention to other influencing factors such as subsurface water temperatures and nutrient supply, etc.

In order to explore the reasons of H1-PME, we ran parallel oxygen, carbon isotopic and $\mathrm{Mg} / \mathrm{Ca}$ ratio measurements on G. ruber and P. obliquiloculata tests. $\mathrm{Mg}$ / $\mathrm{Ca}$ SSTs are derived by the equations of Deckens et al. ${ }^{[25]}$, Lea et al. ${ }^{[26]}$ and Huang et al. ${ }^{[27]}$, respectively. SSTs of coretop samples derived by the equation of Huang et al. ${ }^{[27]}\left(28.0^{\circ} \mathrm{C}\right.$, averaged by spring-summer and fallwinter SSTs) are closer to modern annual $\mathrm{SST}^{[28]}$ at this site, therefore we adopted Huang et al.' $\mathrm{s}^{[27]}$ equation-derived SSTs in this study. Furthermore, we use Anand et al.'s ${ }^{[26]}$ and Huang et al.'s ${ }^{[27]}$ equation to obtain P. obliquiloculata $\mathrm{Mg} / \mathrm{Ca} \mathrm{SSSTs}$, respectively. The difference between the two estimates is about $0.29^{\circ} \mathrm{C}$, which may be caused by the differences between Sargasso Sea and SCS. We use Huang et al.'s ${ }^{[27]}$ estimates because the equation come from SCS. Here we specially addressed the two PMEs in the Holocene and the last deglaciation; detailed $\mathrm{Mg} / \mathrm{Ca}$-derived paleotemperatures will be discussed elsewhere.

$\mathrm{Mg} / \mathrm{Ca}$-derived SSTs vary from $23.7^{\circ} \mathrm{C}$ to $29.8^{\circ} \mathrm{C}$, with a similar trend to that of $\delta^{18} \mathrm{O}$ (Figure 4(b)). They rise from an average of $25.5^{\circ} \mathrm{C}$ in early deglaciation to $28.8^{\circ} \mathrm{C}$ in the Holocene. The $3.3^{\circ} \mathrm{C}$ difference is close to those of the adjacent cores such as MD97-2151 $\left(2.9^{\circ} \mathrm{C}^{[30]}\right)$ and MD01-2390 $\left(3^{\circ} \mathrm{C}^{[22]}\right) . \mathrm{Mg} / \mathrm{Ca}$-derived SSTs show a gradual increase since H1-PME, with no punctuations during the two PMEs (Figure 4(b)), but SSTs derived by transfer functions have a remarkable decrease during the two periods. For instance, winter SSTs of 17962 drop by as much as about $6^{\circ} \mathrm{C}^{[31]}$ between 17 and $15 \mathrm{ka}$. Such differences may be due to the "No-analog" ${ }^{[15,23]}$ problem. That is to say, the low abundance of P. obliquiloculata makes the application of transfer functions in the southern SCS problematic. SSTs from nearby cores (MD97-2151 $1^{[30]}$ and MD01-2390 $0^{[22]}$ ) demonstrate no obvious changes between 17 and $14.8 \mathrm{ka}$, and then it can be concluded that SST declines are not the reason for the PM-Es.

As shown in Figure 4(a)), SSSTs have a fluctuation from 16.0 to $23.2^{\circ} \mathrm{C}$, slightly larger than SSTs. Both of them show a similar trend to $\delta^{18} \mathrm{O}$, that is, an increasing trend towards the Holocene. Different from SSTs, SS-

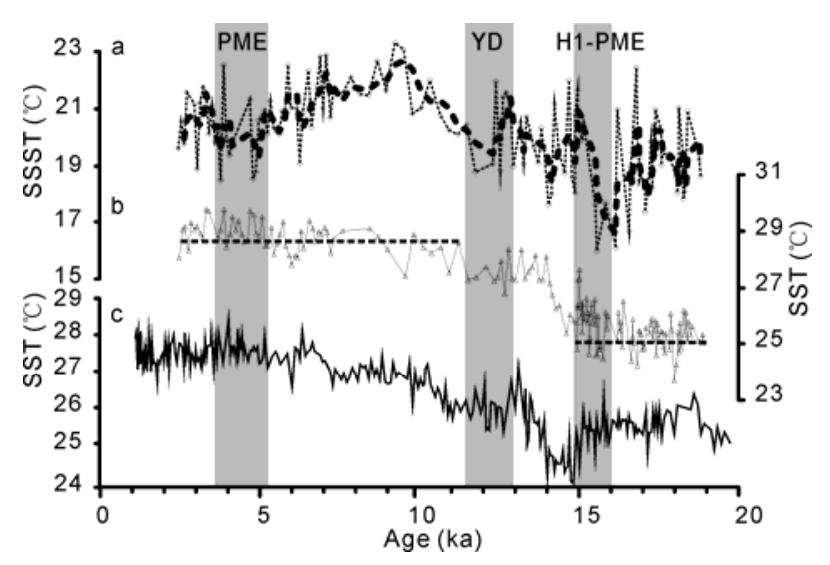

Figure 4 SSTs and SSSTs of MD 05-2894 and SST comparisons between MD 05-2894 and MD97-2151. a, Mg/Ca-derived SSST, 3point smoothed values are represented by dashed line; $\mathrm{b}, \mathrm{Mg} / \mathrm{Ca}-$ derived SST, averages of various periods are indicated by dotted lines; c, $U_{K}^{37^{\prime}}$-derived SST of MD97-2151 ${ }^{[30]}$. PME is the Holocene Pulleniatina Minimum Event, and YD is Younger Dryas event. H1PME is the deglacial Pulleniatina Minimum Event correlating to $\mathrm{H} 1$ event.

STs continuously decrease after reaching its maximum in early to mid-Holocene, which displays a similar trend to that of Timor Sea ${ }^{[8]}$. The warming process of subsurface water was interrupted in the Holocene PME, H1PME and YD event. SSSTs decline as much as $\sim 3.1^{\circ} \mathrm{C}$, $4.8^{\circ} \mathrm{C}$ and $3.1^{\circ} \mathrm{C}$ in the three periods, respectively, the most obvious among which is the $\sim 2^{\circ} \mathrm{C}$ decrease in average during H1-PME.

Previous studies demonstrated that the $\delta^{18} \mathrm{O}$ differences $\left(\Delta \delta^{18} \mathrm{O}\right)$ of planktonic subsurface dweller such as $P$. obliquiloculata and surface dweller such as $G$. ruber can be used to indicate the relative depth of thermocline. Large $\Delta \delta^{18} \mathrm{O}$ indicate a shallow thermocline, and vice versa $^{[7,32]}$. So do the temperature gradients $(\Delta T)$ between SSTs and SSSTs. Large $\Delta T$ indicate a shallow mixed layer, and vice versa. During the deglacial PME, SSTs show no obvious declines while SSSTs have an average decrease of $\sim 2^{\circ} \mathrm{C}$, so $\Delta T$ becomes larger, which means a shallow thermocline then. The shallow thermocline is also indicated by larger $\Delta \delta^{18} \mathrm{O}$ values during the PMEs. Besides, both $\Delta \delta^{18} \mathrm{O}$ and $\Delta T$ show a deep thermocline in the early deglaciation and a shallow thermocline in the Holocene. H1-PME occurred exactly during the transition of the two stages. The SSSTs decrease and upper ocean structure changes (Figure 5) influence the habitat of P. obliquiloculata and cause the low abundance of this species.

The Holocene PME is widely distributed in marginal seas of the western Pacific, but H1-PME is only documented in the southern SCS, so some unique paleocean- 


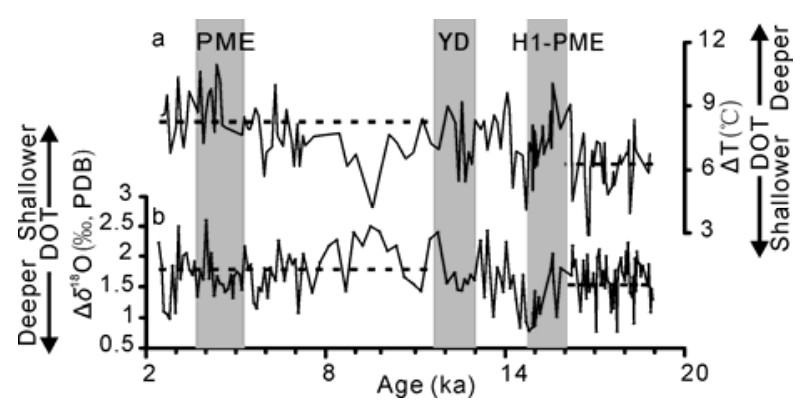

Figure 5 The temperature gradients $(\Delta T)$ between SSTs and SSSTs, and the $\delta^{18} \mathrm{O}$ differences $\left(\Delta \delta^{18} \mathrm{O}\right)$ between $P$. obliquiloculata and $G$. ruber. a, The temperature gradients $(\Delta T)$ between SSTs and SSSTs; b, the $\delta^{18} \mathrm{O}$ differences $\left(\Delta \delta^{18} \mathrm{O}\right)$ between $P$. obliquiloculata and $G$. ruber. PME is the Holocene Pulleniatina Minimum Event, and YD is Younger Dryas event. H1-PME is the deglacial Pulleniatina Minimum Event correlating to $\mathrm{H} 1$ event.

ographic changes may exist in the southern SCS during the last deglacial warming period. Koutavas et al. ${ }^{[33]}$ compared SSTs of V21-30 in the eastern Pacific with 18287 in the southern SCS and implied a more El Nino-like condition between 17.0 and $14.8 \mathrm{ka}$, which is contemporary with H1-PME in the southern SCS. But there is no such event in the western equatorial Pacific ${ }^{[8]}$, so H1-PME cannot be ascribed to the tropical factors like ENSO. Here we present the following hypothesis about the reasons of H1-PME. One is related to that North Atlantic Deep Water (NADW) weakens while North Pacific Deep Water (NPDW) strengthens during $\mathrm{H}{ }^{[34]}$. Cold NPDW upwells to be subsurface water when blocked in the southern SCS; then SSSTs decrease; the thermocline shoals and the abundance of P. obliquiloculata drop. Another hypothesis is that seaways connecting the southern SCS with Indian and Pacific Ocean gradually open during the last deglaciation. The restructured upper ocean makes subsurface dweller P. obliquiloculata absent in this region. Furthermore, forced by winter monsoon, the mixed layer in the upper SCS will deepen. When the meridional seawater temperature gradient increases, the thermocline is best ventilated. More surface water from the northern SCS mixed layer is drained into the upper seasonal thermocline; moves southward and becomes subsurface water of the southern SC$S^{[35]}$. Then the southern SCS SSSTs show an obvious decline; the thermocline shoals; and P. obliquiloculata decrease. In order to understand the reasons why SSSTs decline during H1-PME, further studies are still needed to discuss the links between various paleoceanographic changes.

\section{Conclusions}

Based on a careful planktonic foraminiferal faunal census count, we discovered that $P$. obliquiloculata nearly disappears between 16.0 and $14.9 \mathrm{ka}$ in the southern SCS. This interval correlates well with the Heinrich 1 cooling event. The H1-PME is extensively documented in the southern SCS, thus can be a good stratigraphical indicator in this region. $\mathrm{Mg} / \mathrm{Ca}$-derived SSTs gradually increase since the last deglaciation, with little punctuation during the Holocene PME, H1-PME or Younger Dryas event. But SSSTs demonstrate significant decreases during these periods. Both $\delta^{18} \mathrm{O}$ and temperature differences become larger during the two PMEs, indicating the shoaling of the thermocline. The restructured upper ocean may be responsible for the SSSTs decline, which results in the remarkable decrease of $P$. obliquiloculata during the deglacial Pulleniatina Minimum Event. Such restructuring may be caused by the upwelling of NPDW, gradual opening seaways, or better thermocline ventilation during the last deglaciation. Further studies are still needed to know the exact reasons for these changes.

Samples in this study were provided by "Marco Polo" Cruise in 2005 which was sponsored by IMAGES. We sincerely thank all the onboard scientists and the crew. We should also thank Cheng Xinrong and Qiao Peijun for their assistance in isotopic and $\mathrm{Mg} / \mathrm{Ca}$ measurements.
1 Bé A W H. An ecological, zoogeographical and taxonomic review of recent planktonic foraminifera. In: Ramsay A $\mathrm{T} \mathrm{S}$, ed. Oceanic Micropaleontology. London: Academic Press, 1977. 1-100

2 Pflaumann U, Jian Z M. Modern distribution patterns of planktonic foraminifera in the South China Sea and western Pacific: a new transfer technique to estimate regional sea-surface temperatures. Mar Geol, 1999, 156: 41-83

3 Thompson P R. Planktonic foraminifera in the western north Pacific during the past 150000 years: comparison of modern and fossil as- semblages. Palaeogeogr Paleoclimatol Palaeoecol, 1981, 35: 241-279

4 Chen R H, Jian Z M, Zheng Y L, et al. Seasonal variations of the planktonic foraminiferal flux in the central South China Sea (in Chinese with English abstract). J Tongji Univ, 2000, 28: 73-77

5 Li B H, Jian Z M, Wang P X. Pulleniatina obliquiloculata as a paleoceanographic indicator in the southern Okinawa Trough during the last 20000 years. Mar Micropaleontol, 1997, 32: 59-69

6 Jian Z M, Wang P X, Saito Y, et al. Holocene variability of the Ku- 
roshio Current in the Okinawa Trough, northwestern Pacific Ocean. Earth Planet Sci Lett, 2000, 184: 305-319

7 Tian J, Wang P X, Chen R H, et al. Quaternary upper ocean thermal gradient variations in the South China Sea: implications for East Asian monsoon climate. Paleoceanography, 2005, 20: PA4007, doi: 10.1029/2004PA001115

$8 \mathrm{Xu} \mathrm{J}$, Holbourn A, Kuhnt W, et al. Changes in the thermocline structure of the Indonesian Outflow during Terminations I and II. Earth Planet Sci Lett, 2008, 273: 152-162

9 Ujiié Y, Ujiié H. Late Quaternary course changes of the Kuroshio Current in the Ryukau Arc region, northwestern Pacific Ocean. Mar Micropaleontol, 1999, 37: 23-40

10 Lin Y S, Wei K Y, Lin I T, et al. The Holocene Pulleniatina Minimum Event revisited: geochemical and faunal evidence from the Okinawa Trough and upper reaches of the Kuroshio Current. Mar Micropaleontol, 2006, 59: 153-170

11 Li T G, Liu Z X, Hall M A, et al. Heinrich event imprints in the Okinawa Trough: evidence from oxygen isotope and planktonic foraminifera. Palaeogeogr Paleoclimatol Palaeoecol, 2001, 176: $133-146$

12 Jian Z M, Li B H, Pflaumann U, et al. Late Holocene cooling event in the western Pacific. Sci China Ser D-Earth Sci, 1996, 39: 543- 550

13 Peng Y, Xiao J, Nakamura T, et al. Holocene East Asian monsoonal precipitation pattern revealed by grain-size distribution of core sediments of Daihai Lake in Inner Mongolia of north-central China. Earth Planet Sci Lett, 2005, 233: 467-479

14 Wang Y J, Cheng H, Edwards L R, et al. The Holocene Asian monsoon: links to solar changes and north Atlantic climate. Science, 2005, 308: 854-857

15 Jian Z M, Wang B S, Qiao P J. Late Quaternary changes of sea surface temperature in the southern South China Sea and their comparison with the paleoclimatic records of polar ice cores (in Chinese with English abstract). Quat Sci, 2008, 3: 391-398

16 Fairbanks R G, Mortlock R A, Chiu T C, et al. Radiocarbon calibration curve spanning 0 to 50,000 years B.P. based on paired ${ }^{230} \mathrm{Th} /{ }^{234} \mathrm{U} /{ }^{238} \mathrm{U}$ and ${ }^{14} \mathrm{C}$ dates on pristine corals. Quat Sci Rev, 2005, 24: $1781-1796$

17 Wang L J, Sarnthein M, Erlenkeuser H, et al. East Asian monsoon climate during the Late Pleistocene: high-resolution sediment records from the South China Sea. Mar Geol, 1999, 156: 245-284

18 Fang D Y, Cheng X R, Wu G X, et al. Paleoceanographic record of the past $30 \mathrm{ka}$ in the southern Nansha Area, South China Sea (in Chinese with English abstract). Mar Geol Quat Geol, 2000, 20: $81-86$

19 Huang C Y, Chen M T, Lee M Y, et al. Planktic foraminifer faunal sea surface temperature records of the past two glacial terminations in the South China Sea near Wanan Shallow (IMAGES core MD972151). Western Pacific Earth Sci, 2002, 2: 1-14

20 Ujiié Y, Ujiié H, Taira A, et al. Spatial and temporal variability of surface water in the Kuroshio source region, Pacific Ocean, over the past 21000 years: evidence from planktonic foraminifera. Mar Mi- cropaleontol, 2003, 49: 335-364

21 Sun Y B, Oppo D W, Xiang R, et al. Last deglaciation in the Okinawa Trough: subtropical northwest Pacific link to Northern Hemisphere and tropical climate. Paleoceanography, 2005, 20: PA4005, doi:10.1029/2004PA001061

22 Steinke S, Chiu H, Yu P, et al. On the influence of sea level and monsoon climate on the southern South China Sea fresh water budget over the last 22,000 years. Quat Sci Rev, 2006, 1477-1488

23 Steinke S, Yu P, Kucera M, et al. No-analog planktonic foraminiferal faunas in the glacial southern South China Sea: implications for the magnitude of glacial cooling in the western Pacific warm pool. Mar Micropaleontol, 2008, 66: 71-90

24 Moy C M, Seltzer G O, Rodbell D T, et al. Variability of El Niño/Southern Oscillation activity at millennial timescales during the Holocene epoch. Nature, 2002, 420: 162-165

25 Dekens P, Lea D, Pak D, et al. Core top calibration of $\mathrm{Mg} / \mathrm{Ca}$ in tropical foraminifera: refining paleotemperature estimation. Geochem Geophys Geosyst, 2002, 3: 1022, doi:10.1029/2001GC00 0200

26 Lea D W, Pak D, Spero H. Climate impact of Late Quaternary Equatorial Pacific sea surface temperature variations. Science, 2000, 289 $1719-1724$

27 Huang K F, You C F, Lin H L, et al. In situ calibration of $\mathrm{Mg} / \mathrm{Ca}$ ratio in planktonic foraminiferal shell using time series sediment trap: a case study of intense dissolution artifact in the South China Sea. Geochem Geophys Geosyst, 2008, 9: doi:10.1029/2007 GC001660

28 Levitus S, Boyer T P. World Ocean Atlas 1994: Temperature. NOAA Atlas NESDIS, Vol. 4. Washington D C U.S. Department of Commerce, 1994

29 Anand P, Elderfiled H, Conte M. Calibration of $\mathrm{Mg} / \mathrm{Ca}$ thermometry in planktonic foraminifera from a sediment trap time series. Paleoceanography, 2003, 18: 1050, doi:10.1029/2002PA 00846

30 Zhao M X, Huang C Y, Wang C C, et al. A millennial-scale $U_{\mathrm{k}}{ }^{37}$ ' sea-surface temperature record from the southern South China Sea $\left(8^{\circ} \mathrm{N}\right)$ over the last 150kar: monsoon and sea-level influence. Palaeogeogr Paleoclimatol Palaeoecol, 2006, 236: 39-55

31 Li B H, Jian Z M, Huang B Q, et al. Sea surface temperature estimate and subsurface water evolution in the southern South China Sea (in Chinese with English abstract). J Micropaleontol, 2004, 21: 37-43

32 Jian Z, Huang B, Lin H, et al. Late Quaternary upwelling intensity and East Asian monsoon forcing in the South China Sea. Quat Res, 2001, 55: 363-370

33 Koutavas A, Stieglitz J, Marchitto T, et al. El-Niño-Like Pattern in Ice Age Tropical Pacific Sea Surface Temperature. Science, 2002, 297: $226-230$

34 Sarnthein M, Thorsten K, Grootes P, et al. Warmings in the far northwestern Pacific premoted pre- Clovis immigration to America during Heinrich Event 1. Geology, 2006, 34: 141-144, doi:10.1130/G 22200.1

35 Wang D X, Du Y, Shi P. Evidence for thermocline ventilation in the South China Sea in winter. Chinese Sci Bull, 2001, 46: 774-778 